\title{
Distance Education And Learning Styles: Some Interesting Results
}

Ronald B. Marks, (Email: marks@uwosh.edu), University of Wisconsin, Oshkosh Stanley D. Sibley, University of Wisconsin, Oshkosh

\begin{abstract}
The rush to offer web courses has left many questions as to what makes them effective and satisfactory. Important issues are: the perceived advantages of web-based courses; appropriate pedagogical tools (e.g., streaming media, PowerPoint presentations) to facilitate student-content interaction, media richness, and the influence of antecedent characteristics, such as gender, experience, motivation, and learning styles. Research here indicates support for media richness, web-based course advantages, some pedagogies, and minimal support for learning styles, at least Gardner's multiple intelligences and Keirsey's personality styles.
\end{abstract}

\section{INTRODUCTION}

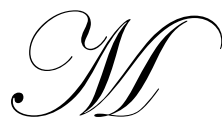

ost current research on distance learning has focused on comparing the traditional learners and the distance learners on differences in success outcomes. The research also indicated that learners regardless of the setting have a variety of different characteristics and behaviors. These differences have included demographic variables such as gender and age, internal variables such as motivation and learning styles, and behavioral variables such as educational experiences and performance outcomes. The reliance on grouping students and finding averages has led to findings on group learning rather than individual learning (Merisotis, 1999).

\section{INDIVIDUAL DIFFERENCES}

The increased use of computers for teaching and learning (Alavi et al., 1997; Webster \& Hackley, 1997) challenged educators to understand which students will adjust and benefit and which students will have difficulty when confronted with computer enhanced teaching. The possibility of matching students to course delivery is one of the holy grails of professional education (Card, 2000; E. R. Green, 1999; Takacs, Reed, Wells, \& Dombrowski, 1999; Twigg, 1994). Cronbach and Snow (1977) noted: "What lies before us is the task of accumulating knowledge about how a person's characteristics influence his or her response to the alternatives educators can offer or invent." Czaja, et al. (1998) wrote: "In summary, existing studies suggest that user characteristics account for a large amount of variability in computer task performance." Similarly, studies of computer mediated communication (CMC) showed participation varied with individual differences. When Davis and Ralph (2001) received disappointing participation in CMC they identified issues of gender, culture, experience, and attitude to account for communication variations. It is intuitive that personal characteristics and demographics should be related to learner outcomes with web-courses. Whether age, GPA, and gender of the student are related to web-based course perceptions on learning and satisfaction is still open because the research has been inconclusive.

Information on individual differences can increase our ability to design curricula, to instruct and to advise students. Sonwalkar (2002) said "online learning provides tremendous opportunity for providing pedagogical choices to learners that cannot be provided by a single professor or teacher in a classroom situation. Online education provides a unique opportunity to use multiple representations of knowledge in terms of media. At the same time, it also provides opportunity to sequence this knowledge in a way so that it makes more pedagogical sense, by providing different learning strategies." Some writers have suggested to go beyond individual differences of characteristics and to add learning styles for analysis. Litzinger and Osif (1993) described learning styles as "the different ways in which children and adults think and learn." Accordingly, learners create a consistent approach for learning. Therefore, 
students can be become more engaged in the learning process if the faculty will create more exercises and assignments based on the learning styles of the students. Technological tools of streaming videos, threaded discussions, and others provided the opportunity to relate to the learning style of the student. These tools coupled with learning styles can change the teaching approaches of faculty (O'Connor, 1997). Accordingly, proper pedagogies and technological tools for identified student learning styles or other relevant student differences can result in on-line interactions as good or better than in the traditional classroom and can provide a better learning experience.

\section{MEDIA RICHNESS}

Does using multiple teaching pedagogies have value in and of themselves, regardless of whether they are specifically targeted at individual student characteristics or learning styles? Media richness (Daft \& Lengel, 1984) and social presence theories (Rice, 1984; Sproull \& Kiesler, 1991) implied differences between the traditional class and the internet class. The on-line class has tended to focus on low level text-based materials without the instructor providing non-verbal cues on expectations and assignments. These characteristics have resulted in the interdependent tasks in group projects and case discussions to be quite demanding for students.

Historically, web-based courses have relied extensively on text-based transmission of course content and discussion. This is true for a number of reasons such as limited bandwidth, concerns over minimum hardware/software requirements for students, and the learning curve required for both students and instructors. It has been suggested that media with higher richness be used to supplement the text-based on-line course experience such as physical meetings (Greco, 1999), videoconferencing (Alavi et al., 1997; Gay \& Lentini, 1995), and the use of voice messaging, video clips and/or multimedia (Bailey \& Kotlar, 1994; Greco, 1999. Research that examines the effects of various types of media on course outcomes is rather limited. In one of the few studies, Arbaugh and Duray (2002) found that the use of varying numbers of audio and/or video clips in a study of thirteen web-based courses was not a significant predictor of student learning or course satisfaction. This finding supported the conclusion that faculty must evaluate the time needed to create and to incorporate these supporting materials and ways to present them (Dumont, 1996; Neumann, 1998). Nevertheless, the jury is still out on the value media enrichments since the technology is still in the beginning stages.

\section{PERSONAL CHARACTERISTICS AND DEMOGRAPHICS OF WEB-BASED STUDENTS}

\section{Gender As A Predictor Of Student Satisfaction}

Gender differences in computing have been a topic of interest. Do women take to the computer to the same degree as men, are they more anxious about computing, do they use the computer differently, do they value different aspects of computing and do they communicate differently when using the computer? The answers to these questions are relevant to pursue because so many distant learners have been adult females (Moore \& Kearsley, 1996; Hardy \& Boaz, 1997).

Many studies of computer mediated communication (CMC) showed gender differences in participation (Arbaugh 2000b, 2000d; Davis and Ralph, 2001; Hancock \& Dunham 2002; Wolfe, 2000), but not all found differences (Murphy \& Collins, 1997; Ory, Bullock, \& Burnaska, 1997). Wolfe (2000) argued: "Research on CMC and gender has found that men tend to contribute more turns and more words to online conferences than women (Herring, 1996; Kramarae \& Taylor, 1993; Selfe \& Meyer, 1991; Wolfe, 2000). However, the results reported in these studies have often been only marginally significant and have rarely approached the huge inequities between male and female discourse found in traditional settings." In her own research she reported that women benefited from CMC opportunities, participated more than they did when face-to-face and expressed greater satisfaction with CMC. Similarly, Arbaugh $(2000 \mathrm{~b}, 2000 \mathrm{~d})$ found the that women made significantly more comments than men in an online MBA strategy course and exhibited a significantly stronger pattern of class participation when compared with both genders in a classroom-based offering of the same course. By contrast, Herring (1996) found that women participated less and that their messages were shorter; he noted "while a short message does not necessarily indicate the sex of the sender, a very long message invariably indicates that the sender is male." 
A difference in CMC norms from general classroom norms may benefit women. Wolfe (2000) noted that the women valued turn-taking that was fostered by the technology employed. Sanders and Stone (1986) suggested that female students, in particular, may be more comfortable in instructional settings, which employed collaborative, rather than individualized, computer learning activities.

Some gender differences may be associated with different learning styles. Blum (1999) studied 149 messages posted over a one-month period from an on-line course and found that men posted 9 percent more messages than women. Women posted 80 percent of all questions, but males posted 75 percent of all responses. Males communicated more using certainty (77 percent of messages) females more with empathy (66 percent of messages). Eighty-three percent of the messages with personal references were from women. Men showed a more separated learning style, while women showed a more connected learning style. Men were more likely to cut women off with use of inappropriate comments. Herring (1996) also noted censorious male communications.

\section{Experience as a Predictor of Student Satisfaction}

Research has shown that computing experience is strongly related to attitudes toward web usage (Atkinson \& Kydd, 1997), computers, and computer usage (Dyck \& Smither, 1994; Thompson, Higgins \& Howell, 1994; Whitley, 1997). For the internet course, this experience has been associated with spending more time in the course, logging on to the course site more frequently, and intending to take additional internet courses in the future (Hiltz, 1994; Ridley \& Sammour, 1994). Students who worked longer on a web-based course and/or who have had taken web-based courses were more likely to be satisfied with this delivery method. It also implied that these students were more probably to take ownership of the learning process and were more likely to increase their own learning. In addition, as students gained experience in using the computer and the internet in a web-based course, they became more at ease with the course and the various components such as bulletin boards and e-mails (Jones and Wolf, 2001).

\section{Self Efficacy}

General belief in self efficacy referred to ".... a general set of expectations that the individual carries into new situations." These generalized expectancies should influence the individual's expectations of mastery in the new situation (Sherer, et al., 1982). Self-efficacy theory was one of the social cognitive theories and differed in its specificity and recognition of the dual cognitive mechanisms that influenced behavior, outcome expectations and personal efficacy or the belief in ability to carry out the task (Bandura, 1986).

This construct has been widely studied in this past decade with consistent results: Self-efficacy, whether one has it before or from training, leads to better learning and performance. Self-efficacy was s a powerful predictor of performance (e.g., Cole \& Latham, 1997; Eden \& Aviram, 1993; Ford et al., 1998; Martocchio 1994; Martocchio \& Webster, 1992; Mathieu et al., 1992; Quinones, 1995; Mitchell et al., 1994; Phillips \& Gully ,1997; Stevens \& Gist, 1997; Stajkovic \& Luthans, 1998). Self-efficacy has also been shown to have motivational effects (e.g., Quinones 1995), to influence training reactions (Mathieu et al., 1992), and to ascertain whether trainees will use training technology (Christoph, R., Schoenfeld, G. \& Tansky, J., 1998). In one of the few studies relating self-efficacy directly to distance education and using a reduced 8-item scale (Tucker, 2003), self efficacy was shown to have a moderate positive correlation with preference for web-based training. In another study (DeTure, 2004) online technologies and self-efficacy scores were poor predictors of student success in online distance education courses.

\section{Learning Styles}

Grasha (1996) defined learning styles as "...personal qualities that influence a student's ability to acquire information, to interact with peers and the teacher, and otherwise to participate in learning experiences." Kolb (1984) concluded that learning style is the result of a process of learning and problem solving that allows people to "create from their experience concepts, rules and principles to guide their behavior in new situations..."

There is a broad consensus on the value of designing curricula that take into account individual learning styles and that it will lead to more effective learning (Brudenell \& Carpenter, 1990; Claxton \& Murrell, 1987; Corno 
\& Snow, 1986; Kevin \& Liberty, 1975; Raschick, Maypole, \& Day, 1998; Riding \& Sadler-Smith, 1992; Sein \& Robey, 1991). Yet, Boles, Pillay and Raj (1999) recently noted, "Even though there is a general acceptance by educators that students differ in how they perceive and process information and attempts to cater for it can be seen in the more traditional instruction, it has not gained the same recognition in the design of CBI [Computer Based Instruction] material."

The primary reason to include learning styles into the delivery has been the problem of different students with different learning styles taking the same course. If the teacher created learning activities addressing only one style, some students will have problems with the assignments while others will flourish. However applying learning styles to teach has been complicated by the multiplicity of theories on learning styles to choose from.

Curry (1983) categorized learning differences from the many theories describing learning styles. She used the "onion concept" and different layers to help explain learning differences. From the outside to the inside layer, she suggested four levels: instructional and environmental preferences, social interaction models, information processing models, and personality models. At one extreme, the Myers-Briggs Type Indicators (Myers \& McCaulley, 1985) represented personality types influencing learning outcomes; Gardner's Theory of Multiple Intelligences (Gardner, $1983,1993,1995,1999)$ reflected the use of information processing models in the classroom and elsewhere.

Accordingly, the Keirsey Temperment Sorter II (1998) and Gardener's Multiple Intelligences (1983, 1993, 1999) were chosen to represent the many models on learning styles. Both theories suggested that teachers need to develop a variety of learning activities to cover the learning styles of students. These learning experiences helping to engage students included individual assignments, group projects, presentations, problems, and cases. These experiences can vary from simple problems to more complex open-ended problems to satisfy different types of learners.

The Keirsey Temperaments were similar to the Myers-Briggs Indicators of personality profiles (trademarked and copyrighted by Consulting Psychological Press). The Keirsey (1998) test placed individuals into four major groups based on responses to a list of questions different than the Meyers and Briggs questionnaire but with similar results (about .75 correlation. The four groups were Guardians, Artisans, Idealists, and Rationals, and the four groups are further divided into two groups each. The four major temperaments with each one having two related groups were as follows [Excerpted and paraphrased from Please Understand Me II, by David Keirsey 1998]:

- $\quad$ Rational NTs, The two main groups were usually involved in marshalling and planning (NTJ organizing) and inventing and configuring (NTP engineering). They have trust in reason and have sought achievement.

- Idealist NFs, These groups were usually involved in teaching and counseling (NFJ mentoring) or conferring and tutoring (NFP advocating). Idealist types searched for their unique identity, sought deep and meaningful relationships, and trusted their intuitive feelings implicitly.

- $\quad$ Artisan SPs. These groups were often involved in promoting (SPT expediting) or composing (SPF improvising). Artisans were graceful, somewhat daring, and confident. The person was likely to seek sensations of all kinds. These groups tended to prefer what is going on at the moment.

- Guardian SJs, These groups often were supervising and inspecting (SJT administering) or protecting (SJF conserving). They were proud of themselves for reliability in action, performing good deeds, and respectability. They trusted legitimacy and desired membership groups as they sought security. They have tended to be businesspeople or to work with materials in vocations.

Howard Gardner $(1983,1993,1999)$ believed that people have multiple intelligences in contrast to a general intelligence and that at least seven intelligences can be identified. The two primary factors contributing to different intelligences were heredity and education. The seven intelligences were aptly named to reflect the umbrella concept of each one. These were: (1) linguistic Intelligence, (2) logical-mathematical intelligence, (3) spatial intelligence, (4) musical intelligence, (5) bodily-kinesthetic intelligence, (6) intrapersonal intelligence, and (7) interpersonal intelligence. All of these intelligences needed to be measured to derive overall intelligence since each person is expected to have varying degrees of each of them. 
Using Gardener's learning styles within the context of enriched media, suggestions (Meacham, 2003) for appropriate pedagogies for students strong on each intelligence might be:

- Visual/spatial intelligence. Pictures are usually the basis of making connections so use pictures

- Verbal/linguistic intelligence. Words are usually the basis of thinking so use lectures, tell stories, interpret classroom materials, exchange of ideas (classroom or internet), and written tests.

- Logical/mathematical intelligence. Logic and numbers are usually the basis of creating connections and linkages so use problem-solving activities, logic puzzles, interpretation of data, and building connected relationships.

- Bodily/kinesthetic intelligence. Physical proficiency within the physical space is usually the key to understanding so use tools to provide hands-on experiences and projects that you much do something physical such as developing sophisticated PowerPoint presentations with animation and audio or having assignments with requirements of physical dexterity to succeed.

- Musical/rhythmical intelligence. Patterns and sounds are typically the basis for thinking so use music clips or CDs, sound effects in lecture, and background sounds.

- Interpersonal intelligence. Stories, feelings of other people, and group activities are usually important for learning so use teams for projects, discussions in class or on the internet, and other assignments.

- Intrapersonal intelligence. Self-awareness and ability to share their feelings are usually important to this group so use expressive activities by focusing on what the person believes and thinks on topics, problemsolutions, and situations or people.

Little published research was found on Gardner's multiple intelligences and distance education. One study (Woods, 2004) directly related Gardner's multiple intelligences to distance education. A correlational study was conducted in which 20 students enrolled in web-based courses with the Blackboard, Inc. platform. An email instrument was administered to investigate students' perceptions concerning web-based instruction before the completion of their courses. The research findings revealed the following: significant correlations existed between student satisfaction with web-base instruction and student ratings of web-based technologies, principles of good practice, and multiple intelligences. Discussion board, course information, email, web links and announcements received higher ratings than the syllabus, journal, file exchange, multimedia and homepage features. Student-faculty contact, student-student collaboration, active learning, and high expectations received higher ratings than prompt feedback, time for a task, and diverse ways of learning. Intrapersonal, interpersonal, visual, and verbal intelligences provided higher ratings than logical, musical, and physical intelligences.

\section{OTHER RESEARCH ON LEARNING STYLES}

Most studies in distance education using learning styles have concentrated on the differences among successful and unsuccessful students or differences of students between distance and campus courses. Dille and Mezack (1991) used Kolb's Learning Style Inventory (LSI) to identify high risk predictors of students taking telecourses at a community college. Less successful students had a stronger preference for concrete learning experiences than the more successful students. The authors suggested that students with high evaluations for concrete experiences might need interpersonal interactions with the teacher and other class members, and the students with low evaluations might be better telecourse learners due to the reliance on one's own skills. This study supported the conclusions from an earlier study by Gee (1990). The focus of his research was the learning styles of students enrolled in a telecourse or in a traditional course. For the telecourse, the more successful students based on achievement had a more conceptual and independent learning style, and the less successful students had a more social and concrete learning style. For comparing the telecourse and the in class course, the students with high social and applied learning styles were more successful in the traditional course. Diaz and Cartnal (1999) used Grasha's Learning Styles Inventory to compare learning styles between students taking distance education or in-class courses. When comparing the students in the two course settings, the students in the distance education course scored higher on independence and lower on dependence.

Research on abstract or independent learning has indicated that in general most students scored low on this type of learning style (Grasha 1996, Lawrence 1982). However, when gender was taken into account, differences 
were found. Using Kolb's Learning Style Inventory (LSI) with undergraduate business students, Stelzer (2001) found that satisfaction with the course and the internet delivery medium was associated with "abstract conceptualization" (AC) for men but with "concrete experience" (CE) for women. For both men and women, AC was associated with higher grades. For women, however, as CE scores increased so did the beliefs that they had successfully mastered the course delivery system and that they achieved the course learning objectives. AC women performed well, but they believed that they failed to achieve the learning objectives and that they failed to state an understanding of the technology.

One study (Velthouse, 2003) compared distance education and personality on extroversion and introversion. It found that extroverted students had a preference on the method of information delivery in internet courses. They liked the use of e-mails, chat rooms and threaded discussions. The introverted students were heavier users of e-mails than other course activities but were lower participators in chat rooms and threaded discussions. Furthermore, intuitive students tended to enjoy Internet courses over in-class courses. Armstrong (2000) argued that he student with the analytic style was more logical, structured, and applied systematic problem-solving, and the student with the holistic/intuitive style was more open, flexible, and impulsive in decision-making. The analytic style relative to the holistic/intuitive style was related to higher performance of the learning outcomes. He believed that business schools favored the "analytic style" over the "holistic/intuitive style." In summary, the research findings on learning styles, personality, and student performance on learner outcomes have not been very encouraging

\section{ADVANTAGES OF WEB-BASED COURSES AS A PREDICTOR OF STUDENT SATISFACTION}

What makes a web course attractive, satisfying and a good learning experience? Two important features of internet courses making them attractive to students were convenience and flexibility (Arbaugh \& Duray, 2001; Fornaciari, Forte, \& Matthews, 1999; Hiltz \& Wellman, 1997; Hislop, 1999; Shapley, 2000; Sullivan, 2001). These benefits included saving commuting time, arranging for an appropriate work schedule, enrolling in a course with limited availability, finishing a degree sooner, and enjoying flexible time for various activities. Recent empirical work, however, finds the flexibility ceases over time as a significant predictor of student learning and satisfaction (Arbaugh, 2002a). Perhaps, students might just have rising expectations on quality learning experiences as their internet course experiences increased causing the perceived flexibility to diminish in importance (DiBiase, 2000; Gibson \& Gibson, 1995).

\section{RESEARCH QUESTIONS}

- $\quad$ RQ1: What are the contributing variables to the learning outcomes desired by instructors?

- RQ2: Do learning styles, self efficacy, individual differences, and benefits of taking internet courses contribute to understanding the perceived learning and satisfaction by students?

- $\quad$ RQ3: Can a difference be found between the two major models on learning styles and learner outcomes?

\section{METHOD}

The evaluation instrument was created to include representative items as major components of internet teaching and learning effectiveness. The sample was collected from graduate business students at a regional state college with an approximately 20 percent response rate, considered good allowing for the length of the questionnaire such as demanded by the 70-item Gardner measure and others.

\section{Dependent Variables}

Student learning items were measured using Alavi's (1994) six-item scale on issue identification, communications on the subject, and integration and generalization of the course material. Student learning included additional items from (Arbaugh \& Duray, 2001). Satisfaction with the course, time and effort required, and decision to take an Internet course was each measured with a seven-item "strongly disagree" to "strongly agree" scale with seven denoting "strongly agree" (Alavi, Wheeler, \& Valacich, 1995; Alavi et al., 1997; Arbaugh, 2000a; Arbaugh \& Duray, 2001; Chidambaram, 1996; Warkentin, Sayeed, \& Hightower, 1997). 


\section{Independent Variables}

The multiple intelligences component consisted of 70 items that were operationalized from Gardner's theory. The subjects used a seven-point Likert scale to assess their strengths in each of the seven intelligences. Both exploratory factor analysis and confirmatory factor analysis were used to produce the most plausible structure for selfrated intelligence (Nokelainen, et. al., 2004). Individual items indicated in the article that best measured each intelligence was used in this research. The general subscale of the Self-Efficacy Scale (GSE) (Sherer \& Adams, 1983; Sherer, et al., 1982) used in this study is a 17-item, five-point, Likert scale. Higher scores equate with higher personal expectations of ability to initiate and persist with a course of action.

Student-content tools and exercises in the internet courses included: chapter outlines, chat rooms, threaded discussion, PowerPoint slides, streaming audio, streaming video, sample test questions, learning objectives, small group discussions, e-mail, self paced internet research, interactive simulations, animation, analyzing case studies, and game-like activities. The effectiveness of these pedagogies was measured via a Likert scale, ranging from very ineffective to very effective. On-line advantages of convenience and flexibility included the ability to enroll in a class that would otherwise be missed, finishing a degree sooner, saving commuting time, arranging a better work schedule, and spending more time on non-work activities (Arbaugh \& Duray, 2001; Fornaciari, Forte, \& Matthews, 1999; Hiltz \& Wellman, 1997; Hislop, 1999; Shapley, 2000, Sullivan, 2001). These items were measured by seven-point "strongly disagree" to "strongly agree" scales with seven denoting "strongly agree."

\section{RESULTS}

A logical first step for the analysis was to begin with the traditional predictors of online learning: sex, age, the number of online courses, and the advantages of taking online courses. Variance explained was 42 percent with two significant independent variables, online course advantages with a beta coefficient of +.572 and number of online courses taken with a beta of +.211 . Learning was operationalized using Varimax Factor Analysis, with the following responses having loadings exceeding .5: "I learned to interrelate the important issues in the course material," "I learned a great deal of factual material in this course," "I gained a good understanding of the basic concepts of the material," "I learned to identify the central issues of the course," "I developed the ability to communicate clearly about the subject," and "I improved my ability to integrate facts and develop generalizations from the course material."

Using the various pedagogies outlined above as independent variables to predict learning resulted in an adjusted variance explained of 34.5 percent. Significant independent variables and their betas were: threaded discussion, +.321; streaming audio +.290; self-paced internet research, +.294 ; stated learning objectives, +.272 ; and small group discussions, -.215 . The latter was especially interesting with its negative coefficient.

Summing the total scores of all pedagogy effectiveness as a measure of media richness, the regression equation was statistically significant with a beta coefficient of +.515 and the variance explained was approximately 26 percent.

Using the gardener multiple intelligence scores as independent variables and learning as the dependent variables, resulted in an adjusted variance explained of $4.8 \%$ with only interpersonal intelligence being significant with a beta of +.233 . Using the four Keirsey styles as predictors of learning, there was no significance whatsoever. Using independent sample t-tests, there were no significant differences in learning styles (either the Gardner or Keirsey model) by gender.

Using self-efficacy as an independent variable as a predictor for learning, there was statistical significance but the variance explained was approximately 6 percent and the beta coefficient was +.259 .

Two major assumptions about learning styles and learning were that: teachers can construct activities that address specific (and multiple) learning preferences and that students will learn better when engaging the learning style in which they're successful. If these assumptions were true, then, knowing which pedagogies were successful with which style(s) is essential. This implied that knowledge of learning styles in combination with pedagogies (an 
interaction effect) should add to the explanatory power. Using Gardner's seven learning styles and creating interaction effects (i.e., multiplying style scores by each pedagogy's perceived effectiveness) and perceived learning as the dependent variable, regression analysis provided the means of testing these hypotheses. Significant interaction effects manifested themselves only for interpersonal intelligence and chapter outlines, chat rooms, e-mail, streaming audio, self-paced internet research, learning objectives, small group discussions, threaded discussion, streaming video, animation, case studies, and games. In terms of additional variance explained, the interactions were marginal. It was of some note that in the regression of just individual Gardner multiple intelligences, chapter outlines, chat rooms, email, streaming video, animation, case studies, and games were statistically insignificant. However, when evaluating the interactions, some significant effects were found for the case of chat rooms, but overall it had a negative beta coefficient. For those high in interpersonal intelligence, the interaction effect was positive. None of the interactions between Keirsey styles and pedagogies proved significant.

\section{DISCUSSION}

On the basis of this research, it appears that the advantages of online learning, pedagogies used, student experience with online courses, self-efficacy (though of limited impact), and media richness do the most for predicting online learning. Knowing learning styles (with the exception of interpersonal intelligence but limited results) does not appear to add much in explanatory power for online learning. Of course, it could be argued that other measures of learning styles, of which, there are many (e.g., Canfield, 1980; Felder-Silverman, 1988; Gregorc, 1979; Kolb, 1984) could be better measures of learning styles. Nevertheless, in the few empirical studies conducted, this finding has yet to be proved conclusively.

Two major problems exist. First, Sternberg (1991) has argued that Gardner's model of multiple intelligences is a "psychometric nightmare" (p. 266). Questions were raised on cultural bias, objectivity, and context-specific evaluations. His point is well-taken and perhaps explains the lack of published research on Gardner's model either from difficulties of trying to operationalize the multiple intelligences or from lack of significant relationships. Also, research by Plucker, Callahan, and Tomchin (1996) showed support for Sternberg's point. Second, the student's ideal or preferred learning style may not fit a concrete or abstract subject to be inculcated and the activities necessary for learning.

In conclusion, the teacher might take the position that exposure to media richness may be the more practical approach to instruction since it would include several learning styles rather than trying to tailor the content and its presentation to specific learning styles (Peng, 2002).

\section{REFERENCES}

1. Alavi, M. (1994). Computer-mediated collaborative learning: An empirical evaluation. MIS Quarterly. 18, 159-174.

2. Alavi, M., Yoo, Y., \& Vogel, D. R. (1997). Using information technology to add value to management education. Academy of Management Journal. 40 (6), 1310-1333.

3. Alavi, M., Wheeler, B. C., \& Valacich, J. S. (1995). Using IT to re-engineer business education: An exploratory investigation of collaborative telelearning. MIS Quarterly. 19, 293-312.

4. Arbaugh, J.B. (2000a). Virtual classroom characteristics and student satisfaction in internet-based MBA courses. Journal of Management Education. 24 (1), 32-54.

5. Arbaugh, J. B. (2000b). Virtual classroom versus physical classroom: An exploratory comparison of class discussion patterns and student learning in an asynchronous internet-based MBA course. Journal of Management Education. 24 (2), 207-227.

6. Arbaugh, J. B. (2000c). Virtual classroom characteristics and student satisfaction in internet-based MBA courses. Journal of Management Education. 24 (1), 32-54.

7. Arbaugh, J. B. (2000d). How classroom environment and student engagement affect learning in internetbased MBA courses. Business Communication Quarterly. 63 (4), 9-26.

8. Arbaugh, J. B. \& Duray, R. (2001). Class section size, perceived classroom characteristics, instructor experience, and student learning and satisfaction with web-based courses: A study and comparison of two 
online MBA programs. In D. Nagao (ed.), Academy of Management Best Papers Proceedings (available on CD-ROM), A1-A6.

9. Arbaugh, J. B. \& Duray, R. (2002). Technological and structural characteristics, student learning and satisfaction with web-based courses: An exploratory study of two MBA programs. Management Learning. 33 (3) 231-247.

10. Armstrong, Steven J. (2000). The influence of individual cognitive style on performance in management education. Educational Psychology. 20 (3).

11. Atkinson, M. \& Kydd, C. (1997). Individual characteristics associated with world wide web use: An empirical study of playfulness and motivation. The DATA BASE for Advances in Information Systems. 28 (2), 53-62.

12. Bailey, E. K. \& Koltar, M. (1994). Teaching via the internet. Communication Education. 43 (2), 184-193

13. Blum, K. D. (1999). Gender differences in asynchronous learning in higher education: Learning styles, participation barriers and communication patterns. Journal of Asynchronous LearningNetworks. 3 (1).

14. Boles, W. W., Pillay, H., \& Raj, L. (1999). Matching cognitive styles to computer-based instruction: an approach for enhanced learning in electrical engineering. Journal of Engineering education. 24 (4), 371-383.

15. Brudenell, I. \& Stewart, C. (1990). Adult learning styles and attitudes towards computer-assisted instruction. Journal of Nursing Education. 29 (2), 79-83.

16. Canfield, A. (1980). Learning styles inventory manual. Ann Arbor, MI: Humanics Media.

17. Card, K. A. (2000). Providing access to graduate education using computer-mediated communication. International Journal of Instructional Media. 27 (3), 235-245.

18. Chidambaram, L. (1996). Relational development in computer-supported groups. MIS Quarterly, 20 (2), 143163.

19. Christoph, R., Schoenfeld, G., \& Tansky, J. (1998). Overcoming barriers to training utilizing technology: The influence of self-efficacy factors on multimedia-based training receptiveness. Human Resource Development Quarterly. 9 (1), 25-38.

20. Claxton, C. \& Murell, P. (1987). Learning styles: Implications for improving education practices. ASHEERIC Higher Education Report No. 4. Washington, D.C.: Association for the Study of Higher Education.

21. Cole N.D. \& Latham, G.P. (1997). Effects of training in procedural justice on perceptions of disciplinary fairness by unionized employees and disciplinary subject matter experts. Journal of Applied Psychology. 82 (5), 699-705.

22. Corno, L. \& R.E. Snow (1986). Adapting teaching to individual differences among learners. In M. Wittrock, ed., Handbook of Research on Teaching. New York: Macmillan.

23. Cronbach, L.J. \& Snow, R.E. (1977). Aptitude and instructional methods: A handbook for research on interaction. New York, NY: Irvington.

24. Curry, L. (1983). An organisation of learning style theory and constructs. In: L. Curry (ed.) Learning Style in Continuing Education. Canada: Dalhousie University.

25. Czaja, S. \& Sharit, J. (1998). Age differences in attitude toward computers. Journals of Gerontology: Series B: Psychological Sciences and Social Sciences. 53B (5), 329-340.

26. Daft, R. L. \& Lengel, R. H. (1984). Information richness: A new approach to manager information processing and organizational design. In B. Staw \& L. L. Cummings (eds.), Research in Organizational Behavior. Greenwich, CN: JAI Press. 6, 191-233.

27. Davis, M. \& Ralph, S. (2001), Stalling the learning process: Group dynamics in cyberspace. Studies in the Education of Adults. 33 (2) October, 217-229.

28. DeTure, Monica (2004). Cognitive style and self-efficacy: Predicting student success in online distance education. American Journal of Distance Education. 18 (1), 21-38.

29. Diaz, D. P. \& Cartnal, R. B. (1999). Students' learning styles in two classes: Online distance learning and equivalent on-campus. College Teaching. 47 (4), 130-135.

30. DiBase, D. (2000). Is distance learning more work or less work? American Journal of Distance Education. 14 (3), 6-20.

31. Dille, B. \& Mezack, M. (1991). Identifying predictors of high risk among community college telecourse students. American Journal of Distance Education. 5 (1), 24-35.

32. Dumont, R. A. (1996). Teaching and learning in cyberspace. IEEE Transactions on Professional Communication. 39 (4), 192-204. 
33. Dyck, J. L. \& Smither, J. A. (1994). Age differences in computer anxiety: The role of computer experience, gender, and education. Journal of Educational Computing Research. 10 (3), 239-248.

34. Eden D. \& Aviram A. (1993). Self-efficacy training to speed reemployment: helping people to help themselves. Journal of Applied Psychology. 78, 352-360.

35. Felder, R.M. \& Silverman, L.K. (1988). Learning and teaching styles in engineering education. Engineering Education. 78 (7), 674-681.

36. Ford, J.K., Smith, E.M., Weissbein, D.A, Gully, S.M., \& Salas, E. (1998). Relationships of goal-orientation, metacognitive activity, and practice strategies with learning outcomes and transfer. Journal of Applied Psychology. 83 (2), 218-233.

37. Fornaciari, C. J., Forte, M., \& Mathews, C. S. (1999). Distance education as strategy: How can your school compete? Journal of Management Education. 23 (6), 703-718.

38. Gardner, H. (1983). Frames of mind. New York: Basic Books.

39. Gardner, H. (1993). Multiple intelligences: The theory in practice. New York, NY: Basic Books.

40. Gardner, Howard (1995). Reflections on multiple intelligences: Myths and messages. Phi Delta Kappan. November, 77 (3), 201.

41. Gardner, Howard (1999). Intelligence reframed: multiple intelligences for the 21st century. New York, NY: Basic Books.

42. Gay, G. \& Lentini, M. (1995). Use of collaborative resources in a networked collaborative design environment. Journal of Computer Mediated Communication. 1 (1). http://www.ascuse.org/jcmc/vol1/issue1/IMG_JCMC/ResourceUse.html

43. Gee, D. G. (1990). The impact of students' preferred learning style variables in a distance education course: A case study. Portales: Eastern New Mexico University. (ERIC Document Reproduction Service No. ED 358 836).

44. Gibson, C. \& Gibson, T. (1995). Lessons learned from 100+ years of distance learning. Adult Learning. 7 (1), 15.

45. Grasha, A.F. (1996). Teaching with style: A practical; guide to enhancing learning by understanding teaching and learning styles. Pittsburgh, PA: Alliance Publishers.

46. Greco, J. (1999). Going the distance for MBA candidates. Journal of Business Strategy. 20 (3), $30-34$.

47. Green, K. C. (1999). When wishes come true: Colleges and the convergence of access, lifelong learning, and technology. Change. 31(2) March-April, 11-15.

48. Gregorc, Anthony F. (1979). Learning/Teaching styles: Potent forces behind time. Educational Leadership. 16 (4) January, 234-236.

49. Hancock, J. \& Dunham, P. (2001). Impression formation in computer-mediated communication. Communication Research. 28, 325-347.

50. Hardy, D. W. \& Boaz, M. H. (1997). Learner development: Beyond the technology. In T. E. Cyrs (ed.), Teaching and learning at a distance: What it takes to effectively design, deliver, and evaluate programs. San Francisco: Jossey-Bass, 41-48.

51. Herring, S. (1996). Bringing familiar baggage to the new frontier: Gender differences in computer-mediated communication. In V. J. Vitanza (ed.), CyberReader, Needham Heights, MA: Allyn \& Bacon, 144-154.

52. Hiltz, S.R. (1994). The Virtual Classroom: Learning Without Limits via Computer Networks. Norwood NJ: Ablex Publishing.

53. Hiltz, S. R. \& Wellman, B. (1997). Asynchronous learning networks as a virtual classroom. Communications of the ACM. 40 (9), 44-49.

54. Hislop, G. W. (1999). Anytime, anyplace learning in an online graduate professional degree program. Group Decision and Negotiation. 8 (5), 385-390.

55. Jones, C. \& Wolf, A. (2001). Evaluating a collaborative online learning environment. Active Learning. 9 , 31-35.

56. Keirsey, David (1998). Please understand me II: Temperament character intelligence. Prometheus Nemesis Book Company.

57. Kevin, R.C. \& Libery, P. G. (1975). Student's personality, attitude, and learning styles as predictors of performance in an undergraduate chemistry course using computer based education. Washington, D.C.: U.S. Educational Resources Information Center. (ERIC Document Reproduction Service No. ED 115 209) 
58. Kramarae, C. \& Taylor, H. J. (1993). Women and men on electronic networks: A conversation or monologue? In Women, Information Technology, and Scholarship, Taylor, H.J., Kramarae,C. \& Ebben, M. (eds.), Center for Advanced Studies, Urbana-Champaign: University of Illinois.

59. Kolb, D.A. (1984). Experiential learning: Experience as the source of learning and development. Englewood Cliffs, N.J.: Prentice-Hall.

60. Lawrence, G. (1982). People Types and Tiger Stripes: A Practical Guide to Learning styles. $2^{\text {nd }}$ ed., Center for Application of Psychological Type, Inc, Gainesville, Fla.: CAPT.

61. Litzinger, M. \& Osif, B. (1993). Accommodating diverse learning styles: Designing instruction for electronic information sources. In Shirato, L. and Arbor, A. (eds.) What is good instruction now? Library instruction for the 90s. Ann Arbor, MI: Pierian Press, 73-81.

62. Martocchio, J. \& Webster, J. (1992). Effects of feedback and cognitive playfulness on performance in microcomputer software training. Personel Psychology. 45, (3) 553-578.

63. Martocchio, J. J. (1994). Effects of conceptions of ability on anxiety, self-efficacy and learning in training. Journal of Applied Psychology. 79 (6), 819-825.

64. Mathieu, E., Tannenbaum, S., \& Salas, E. (1992). Influences of individual and situational characteristics on measures of training effectiveness. Academy of Management Journal. 35, 828-847.

65. Meacham, Margie (2003). E-Learning 1.0: Using multiple intelligence theory in the virtual classroom, Learning Circuits. American Society for Training \& Development (ASTD). Alexandria, Virginia: Enewsletter, June.

66. Merisotis, James P. (1999). Outcomes of distance vs. traditional classroom-based learning, what's the difference? (college-level distance and classroom-based education). Change. 31 (3), 13-17.

67. Mitchell, T.R., Hopper, H., Daniels. D., George-Falvy, J. \& James, L.R. (1994). Predicting self-efficacy and performance during skill acquisition. Journal of Applied Psychology. 79, August, 506-517.

68. Moore, M. G. \& Kearsley, G. (1996). Distance education: A systems view. Belmont, CA: Wadsworth Publishing Company.

69. Murphy, K.L. \& Collins, M.P. (1997). Development of communication conventions in instructional electronic chats. Journal of Distance Education. 12 (1/2), 177-200.

70. Myers, I.B. \& McCaulley, M.H. (1985). Manual: A guide to the development and use of the Myers-Briggs type indicator. Palo Alto, CA: Consulting Psychologists Press.

71. Neumann, P. G. (1998). Risks of e-education. Communications of the ACM, 41 (10), 136.

72. Nokelainen, P., Tirri, H., Tirri, K., \& Komulainen, E. (2004). Conceptual modeling of self-rated intelligence-profile. Self-Concept Research: Driving International Research Agendas. http://citeseer.ist.psu.edu/573304.html

73. O' Connor, Terry (1997). Using learning styles to adapt technology for higher education. Indiana State University, Center for Teaching and Learning Styles Site. http://web.indstate.edu/ctl/styles/learning.html\#STYLES

74. Ory, J.C., Bullock, C., \& Burnaska, K. (1997). Gender similarity in the use of and attitudes about ALN in a university setting. Journal of Asynchronous Learning Networks. 1,39-51.

75. Peng, Lim Lum (2002). Applying learning style in instructional strategies. Learning Styles. 5 (7) October, 2.

76. Phillips, J.M. \& Gully, S.M. (1997). Role of goal orientation, ability, need for achievement, and locus of control in the self-efficacy and goal setting process. Journal of Applied Psychology. 82 (5), $792-802$.

77. Plucker, J. A., Callahan, C. M., \& Tomchin, E. M. (1996). Wherefore art thou, multiple intelligences? Alternative assessments for identifying talent in ethnically diverse and economically disadvantaged students. Gifted Child Quarterly. 40, 81-92.

78. Quinones, M.A. (1995). Pretraining context effects: training assignment as feedback. Journal of Applied Psychology. 80 (2), 226-238.

79. Raschick, M., Maypole, D.E., \& Day, P.A. (1998). Improving education through Kolb's learning theory. Journal of Social Work Education. 34, 31-42.

80. Rice, R. E. (1984). The new media: Communication, research, and technology. Beverly Hills, CA: Sage.

81. Riding, R.J. \& Sadler-Smith, E. (1992). Type of instructional material, cognitive style and learning performance. Educational Studies. 18, 323-340.

82. Sanders, J. \& Stone, A. (1986). The neuter computer: Computers for girls and boys. New York: NealSchuman. 
83. Sein, M. \& Robey, D. (1991). Learning style and the efficacy of computer training methods. Perceptual and Motor Skills. 72, 243-248.

84. Selfe, C. L. \& Meyer, P. R. (1991). Testing claims for on-line conferences. Written Communication. $8,163-192$.

85. Shapley, P. (2000). Online education to develop complex reasoning skills in organic chemistry. Journal of Asynchronous Learning Networks. 4 (2).

86. Sherer, M., Maddox, J., Mercandate, B., Prentice-Dun, S., Jacoba, B., \& Roger R. (1982). The self-efficacy scale: Construction and validation. Psychological Reports. 51, 663-671.

87. Sherer, M. \& Adams, C. (1983). Construct validation of the self-efficacy scale, Psychological Reports. 53 (3), 899-902.

88. Sproull, L. \& Kiesler, S. (1991). Connections: New ways of working in the networked organization. Cambridge, MA: MIT Press.

89. Stajkovic. A.D. \& Luthans F. (1998). Self efficacy and work-related performance: A meta-analysis. Psychological. Bulletin. 124 (2), 240-261.

90. Sternberg, R. J. (1991). Death, taxes, and bad intelligence tests. Intelligence. 15 (3), 257-269

91. Stevens, C.K. \& Gist, M.E. (1997). Effects of self-efficacy and goal-orientation training on negotiation skill maintenance: what are the mechanisms? Personnel Psychology. 50, 955-78.

92. Sonwalkar, Nishikant (2002). Online education must capitalize on students' unique approaches to learning, scholar says. The Chronicle of Higher Education. 48 (17) March 4.

http://chronicle.com/free/2002/03/2002030401u.htm

93. Stelzer, L. (2001). Student satisfaction with computer mediated instruction: Path-goal leadership using instructor verbal immediacy strategies. Paper presented at the Eastern Academy of Management meetings.

94. Sullivan, P. (2001). Gender differences and the online classroom: Male and female college students evaluate their experiences. Community College Journal of Research and Practice. 25 (10), 805-818.

95. Takacs, J., Reed, W. M., Wells, J. G., \& Dombrowski, L. A. (1999). The effects of online multimedia project development, learning style, and prior computer experiences on teachers' attitudes toward the internet and hypermedia. Journal of Research on Computing in Education. 31 (4), 341-355.

96. Thompson, R. L., Higgins, C. A., \& Howell, J. M. (1994). Influence of experience on personal computer utilization: Testing a conceptual model. Journal of Management Information Systems. 11 (1), 167-187.

97. Tucker, Shelia Y. (2003). A portrait of distance learners in higher education. Turkish Online Journal of Distance Education-TOJDE. 4 (3) June.

98. Twigg, C.A. (1994). The changing definition of learning. Educom Review. 29 (4), 23-25.

99. Velthouse, Betty (2003). Online education: Factors that influence its success. University of Michigan- Flint School of Management Working Paper Series, No: 2003-04. www.umflint.edu/resources/offices/provost/report0203.pdf

100. Warkentin, M. E., Sayeed, L., \& Hightower, R. (1997). Virtual teams versus face-to-face teams: An exploratory study of a web-based conference system. Decision Sciences. 28 (4), 975-996.

101. Webster, J. \& Hackley, P. (1997). Teaching effectiveness in technology-mediated distance learning. Academy of Management Journal. 40 (6), 1282-1309.

102. Whitley, Jr., B.E. (1997). Gender differences in computer-related attitudes and behavior: A meta-analysis. Computers in Human Behavior. 13, 1-22

103. Wolfe, J. (2000). Gender, ethnicity, and classroom discourse: Communication patterns of Hispanic and white students in networked classrooms. Written Communication. 17 (4), 491-520.

104. Woods, Gary Cornelius (2004). Student perceptions of web-based technologies, principles of good practice and multiple intelligences. DAI-A 65/03, 904. 